\title{
Die pastorale terapeut as begeleier van ' $n$ persoon met seksueel afwykende gedrag: 'n Hermeneutiese hoek
}

\author{
Author: \\ Stella D. Potgieter ${ }^{1}$ \\ Affiliation: \\ ${ }^{1}$ Department of Practical \\ Theology, Potchefstroom \\ Campus, North-West \\ University, South Africa \\ Correspondence to: \\ Stella Potgieter \\ Email: \\ stellapotgieter@gmail.com \\ Postal address: \\ Williamstraat, Matjiesbult, \\ 38 Helen's walk, Wilkoppies, \\ Klerksdorp 2571, \\ South Africa \\ Dates: \\ Received: 10 May 2011 \\ Accepted: 02 Sept 2012 \\ Published: 12 Dec. 2012 \\ How to cite this article: \\ Potgieter, S.D., 2012, 'Die \\ pastorale terapeut as \\ begeleier van ' $n$ persoon \\ met seksueel afwykende \\ gedrag: 'n Hermeneutiese \\ hoek', In die Skriflig/In Luce \\ Verbi 46(2), Art. \#66, 9 pages. \\ http://dx.doi.org/10.4102/ \\ ids.v46i2.66
}

(C) 2012. The Authors. Licensee: AOSIS OpenJournals. This work is licensed under the Creative Commons Attribution License.
Voordat 'n pastorale terapeut 'n persoon met seksueel afwykende gedrag in die vorm van pedofilie, pastoraal bedien, is daar merkers wat in gedagte gehou moet word ten opsigte van die posisionering van die pastorale terapeut. Daar word aangeneem dat pedofilie nie genees kan word nie, maar slegs beheer en bestuur kan word. Pedofilie is nie net ' $n$ saak vir ander wetenskappe nie, maar beslis ook 'n geestelike saak. Die persoon wat kinders molesteer, beleef dikwels 'n geestelike vakuum. As gevolg hiervan is sy geestelike dimensie remmend en destruktief. ' $n$ Pastorale hermeneutiek is hier uiters belangrik. Dit beteken dat die pastorale terapeut die taak het om God se teenwoordigheid en verhaal vir die persoon met afwykende seksualiteit te vertolk, sodat sy behoeftes, lewenservaringe en nood in die lig van God se liefde en genade in sy lewe sal sin maak. Die pastorale terapeut kan die deelnemer help om te ko-konstrueer sonder om deskundige kennis op hom af te dwing. 'n Pastoraalterapeutiese vertrouensverhouding en onvoorwaardelike aanvaarding moet sigbaar wees om die belangrikste medium van verandering en genesing te bewerkstellig. Wanneer die pastorale terapeut in verbondenheid met Christus self tot nederige diensbaarheid en medemenslikheid gesuiwer word, kom ' $n$ ware pastoraal-terapeutiese verhouding van vertroue en onvoorwaardelike aanvaarding tot stand. Die pastorale terapeut behoort eers sy of haar eie vertrekpunte rakende pedofilie uit te klaar. Hy of sy sal met sy of haar eie seksualiteit, asook die van ander, gemaklik moet wees. Hierdie navorsing kan pastorale terapeute aanmoedig om ' $n$ bydrae te lewer in die bemagtiging van die pedoseksuele persoon op geestelike gebied en sodoende ' $n$ bydrae tot 'n veiliger gemeenskap lewer.

The pastoral therapist as companion of a person displaying sexually deviant behaviour: A hermeneutic angle. Before a pastoral therapist can counsel a person who displays sexually deviant behaviour in the form of paedophilia, there are certain markers pertaining to the therapist's own positioning that must be observed. It is generally accepted that paedophilia cannot be cured, only controlled and managed. However, paedophilia is not only an issue to be studied by other sciences, it is also a spiritual matter. The person who molests children often harbours a spiritual vacuum within him- or herself. The spiritual vacuum, of which the paedophile may be cognisant or unaware, is the determining factor to which a spiritual dimension that is both restraining and destructive can be attributed. A pastoral hermeneutics is imperative in counselling the paedophile. The pastoral therapist must explain God's presence and story to the person displaying deviant sexuality to enable him or her to make sense of his or her needs, life experiences and destitution in the light of God's love and grace. Without imposing specialist knowledge upon the participant, the pastoral therapist can assist him or her to co-construct. A therapeutic relationship based on trust and unconditional acceptance is crucial. The process of change and healing can only be brought about within the parameters and liberty of such a relationship. The pastoral therapist should firstly consider his or her own views regarding paedophilia. He or she must be comfortable with his or her own sexuality, as well as the sexuality of others. The following article aims to encourage pastoral therapists to contribute to the empowerment of the pedosexual person on a spiritual level, and in doing so, contribute to a safer community.

\section{Inleiding}

Hierdie artikel handel hoofsaaklik oor die pastorale terapeut wat persone met disfunksionele seksualiteit in die vorm van pedofilie binne die praktiese teologie begelei. Die terapeut se posisie word hermeneuties benader.

Die geestelike of godsdienstige gevolge van pedofilie wys duidelik dat pastorale begeleiding onontbeerlik is in die helingsproses, dermate dat, indien pastorale insette buite rekening gelaat word, dit 'n onvoldoende helingsproses tot gevolg sal hê (Potgieter 2009:193-219). Daar word dus 'n holistiese benadering voorgestel, omdat seksualiteit ook 'n geestelike kwessie is, en heling van God se genade die psigologie, sosiale en skeppingsdimensies (natuur) van die mens 
insluit (Louw 1999:511). Psigiatriese en mediese behandeling is onteenseglik van groot belang vir die pedofiel, maar die pastorale begeleiding van hierdie persoon kan nie geïgnoreer word nie.

In Suid-Afrika is daar geen gestruktureerde programme of behandeling vir die persoon wat aan die afwykende gedrag pedofilie ly nie (Hesselink-Louw \& Schoeman 2003:163). Die sosiale wetenskappe skenk ook baie min aandag aan seksueel afwykende gedrag tydens hulle opleiding (Britz 2003:192). Die pastoraat behoort op die voorgrond van hierdie veld te wees, omdat seksueel afwykende gedrag nie net 'n saak vir die psigiatrie en reg behoort te wees nie. Die persoon wat kinders molesteer, beleef ' $n$ geestelike vakuum.

Voordat ' $n$ pastorale terapeut hom- of haarself ${ }^{1}$ beskikbaar kan stel vir die pastoraal terapeutiese proses met ' $n$ persoon wat seksueel afwykende gedrag openbaar, is dit belangrik dat die terapeut hom- of haarself eers ten opsigte van pedofilie moet posisioneer. Pastorale terapie verwys na 'n toestand van heling, verandering en groei as uitvloeisel van die kommunikasie van die evangelie en/of heil. Dit verteenwoordig die helende dimensie van herstel en groei (Louw 1999:28). Terapie is wesenlik 'n Christelike saak en is nie vreemd aan die Christelike tradisie nie. Terapie is nie 'n begrip wat deur die mediese wêreld of die psigologie uitgevind is nie. Christus se eie bediening word in die Nuwe Testament as terapie beskryf wanneer na sy dienskneggestalte verwys word as therapeuein. In die Nuwe Testament verwys terapie na hulp en diens wat voortspruit uit die offergestalte van Christus se neerbuigende liefde en God se barmhartigheid (Louw 1999:427).

Die probleemstelling van hierdie artikel is derhalwe die hermeneutiese hoek waaruit die pastorale terapeut 'n persoon met seksueel afwykende gedrag sal benader.

\section{'n Leemte in pastorale terapie}

Kliniese definisie van pedofilie word bepaal deur die Diagnostic and Statistical Manual of Mental Disorders (American Psychiatric Association 2000:527). Volgens hierdie publikasie is die diagnostiese kriteria vir pedofilie die volgende:

- Herhalende, intense seksuele fantasieë, seksuele drange of gedrag wat seksuele aktiwiteit met 'n pre-pubertale kind of kinders (gewoonlik 13 jaar en jonger) insluit.

- Die persoon reageer op sy seksuele drange, of die seksuele drange en fantasieë veroorsaak klinies beduidende stres of belemmering in interpersoonlike funksionering.

- Die persoon is ten minste 16 jaar oud en ten minste vyf jaar ouer as die kind of kinders.

'n Verdere omskrywing is dat 'n pedofiel 'n manlike of vroulike volwassene is wat voorkeur gee aan seksuele kontak met kinders van dieselfde, die teenoorgestelde of albei geslagte op 'n meestal nie-gewelddadige wyse. Hy

$1.0 m$ die enigsins lomp skryfwyse van 'hy of sy' te omseil, word daar vervolgens soms na die terapeut as vroulik en die kliënt as manlik verwys. Dit is bloot ' $n$ gerieflikheids besluit en die bedoeling is geensins seksisties nie. of sy ervaar herhaalde, intense seksuele opwekking deur fantasieë en hy of sy het gedurige drange om met 'n kind onder sestien seksueel te verkeer, met of sonder penetrasie (Potgieter 2009:62).

Nie alle pastorale terapeute wil hulleself beskikbaar stel vir hierdie taak nie. Simpatie lê by die slagoffer, maar wat somtyds vergeet word, is dat hierdie persoon moontlik ook eens 'n slagoffer van molestering (Standford 1988:91; O’Hagan 1993:52; Sweeney 2008:9; Pryor 1996:261; Potgieter 1997:181) of mishandeling (Pryor 1996:159) was. Hy of sy was 'n onskuldige kind wat in 'n gevaarlike volwassene ontaard het (Howitt 1995:60; Hall \& Hall 2007:464). Daar is sommige slagoffers wat nie die krag het om terug te veg nie, en dit is dan ook hierdie slagoffers wat die siklus van seksuele molestering kan herhaal. Hulle innerlike pyn word uitwaarts geprojekteer deur te molesteer. Ryan (1989:326) meen dat pedofiele wat nie die effek van hulle eie molestering erken nie, ook nie die skade erken wat hulle hulle slagoffers aandoen nie.

Die intense stigma wat aan oortreders kleef, veroorsaak dat pastorale terapeute soms nie kans sien om op 'n trans-psigiese vlak, rakende die persone se spiritualiteit en geloofsfunksies, sowel as hulle verhouding met God, by hulle probleme betrokke te raak nie. Dus raak hierdie persoon net meer geïsoleerd en raak molestering net makliker. Alleen wanneer pedofiele die stilte verbreek, kan 'n bydrae tot navorsing gelewer word en 'n beter en dieper insig van hierdie komplekse afwyking verkry word.

'n Verdere rede waarom die pastoraat nie by die persoon met afwykende gedrag betrokke wil raak nie, is dat literatuur daarop wys dat pedofilie 'n komplekse afwyking is wat nie genees kan word nie, maar slegs beheer en bestuur kan word (Salter 1995:44; O’Hagan 1993:194, 197; Wolfaardt 2003:382). Pastorale terapeute voel dat beheer en bestuur nie 'n uitkoms is nie, maar besef nie dat dit al moontlike uitkoms vir hierdie verskynsel is nie.

Desnieteenstaande die aanname dat pedofilie nie genees kan word nie, is dit belangrik vir die pastorale terapeut om te glo dat die persoon wel vry van simptome kan word. Die woord onmoontlik moet dus uit die woordeskat van die pastorale terapeut verwyder word. Indien die terapeut nie in die persoon se heelwording glo nie, hoe kan daar by hom 'n toekomsverwagting geskep word? Die grootste taak van die pastorale terapeut sal wees om vir die seksuele oortreder weer hoop te gee. Indien die terapeut haar met hierdie paradigma vereenselwig, word dit geïntegreer as deel van haar menswees en dus ook haar benadering tot terapie. Christusgelykvormige aanvaarding, genade en kompromislose fokus op die krag van God by die terapeut, is 'n magtige instrument. Dit kan die geloofspad tot verandering en genesing vir die pedofiel ontsluit. Dit kan die pedofiel by die hoopgewende en lewensveranderende Skriffeit bring: niks is vir God onmoontlik nie (Jer 32:17).

Die pastorale terapeut wat haarself beskikbaar stel, moet haar eie onderliggende vooroordele aangaande die persoon uitklaar. Taibbi (1996:8) sê in hierdie verband: '... we need to 
first step back and look at the landscape and decide what we believe.' Die verskuiwing van een epistomologie na 'n ander geskied nie oornag nie en is 'n geleidelike, asook 'n intellektueel uitdagende proses. 'n Persoon met afwykende seksuele gedrag se toetrede tot pastorale terapie sou 'n bydrae kon lewer tot die samelewing deurdat kinders beskerm word en die bose kringloop van pedofilie gestop word, want hierdie handelinge laat littekens op die persoon, sowel as op die samelewing.

In die terapeutiese benadering is dit die pastorale terapeut se funksie om 'n optimale klimaat vir pastoraal-terapeutiese groei te skep. Sodoende word 'n veilige omgewing daargestel waarin die persoon se natuurlike potensiaal na vore kom. Dit stel hom dan in staat om sy eie groei en verandering te genereer. 'n Gunstige terapeutiese klimaat word deur die pastorale terapeut se terapeutiese egtheid, warmte, kongruensie en empatie geskep. Dit is die primêre voorwaarde vir suksesvolle pastorale terapie, en sal die terapeut in staat stel om empaties te kan toetree tot die leefwêreld van die deelnemer.

Aangesien hierdie artikel teen die agtergrond van Skrifbeginsels en vir die pastoraat geskryf is, is 'n hermeneutiese benadering in terapie met die pedofiel onontbeerlik.

\section{Hermeneutiek se etimologiese en epistemologiese wortels}

Die woord hermeneutiek se betekenis lê in die Griekse gebruik van die woorde hermeneuein/hermeneia en verwys na drie verskillende sake, naamlik 'n mondelinge weergee (om te sê); 'n verduideliking van 'n situasie; en die vertaling vanuit 'n vreemde taal (Palmer 1969:14). Schmidt (2006:6) verduidelik die Griekse hermeneuein as 'express aloud, to explain or interpret and to translate'. Die Latynse woord interpretatione kom voor in die werk van Aristoteles (De Interpretatione), waarvan die Engelse en Afrikaanse woorde interpretation en interpretasie afgelei is (Steyn 2008:249).

Oor die jare het daar 'n belangrike klemverskuiwing in ons siening van hermeneutiek plaasgevind, nie die eksegetiese metodes nie, maar die proses van verstaan is allengs beklemtoon (Le Roux 2009).

Gedurende die laaste twee dekades het die gesigskring van hermeneutiek verbreed. Dit is nie meer slegs teks en kunswerke wat interpreteer word nie, maar ook menslike gedrag in die algemeen, sowel as taal, patrone van taal en rituele (waaronder geestelike en politieke rituele, en sportbyeenkomste).

Die postmoderne aanwending van hermeneutiek sluit by Nietzscheaan, naamlik dat daar geen objektiewe feite bestaan nie en daarom is daar geen feite nie, maar net interpretasies (Janse van Rensburg 2000:11-12). Hermeneutiese doelwitte is nie eksklusief tot 'n postmoderne epistemologie nie, maar die teologiese fundering in ' $n$ deduktiewe benadering gee wel 'n ander betekenis aan daardie doelwitte (Janse van Rensburg 1999:159). Hierdie siening word aanvaar en geld vir hierdie artikel.
Louw (1998) bied die volgende tegniese definisie vir hermeneutiek aan, wat help om die essensie van hermeneutiek te verstaan:

As a technical term, hermeneutics simply refers to interpretation. It describes the science or principles of interpretation. It illuminates the movement of understanding and communication between two entities or texts. (bl. 102)

In kort dui die definisie aan dat hermeneutiek betekenisoordrag in 'n kommunikasieproses behels (Louw 1998:98).

Hermeneutiek word omskryf as die studie van begrip deur interpretasie (Pieterse 1993:1; Janse van Rensburg 2000:12).

Sommige invloedryke teoloë (Schleiermacher, Bultmann, Ebeling) en sommige invloedryke filosowe (Dilthey, Heidegger, Ricoeur, Gardamer) gebruik die woord hermeneutiek in 'n bepaalde filosofiese sin wat te doen het met hoe iets uit die verlede, of hoe woorde uit die verlede betekenis vir vandag kan hê, of eksistensieel betekenisvol kan word in die moderne wêreld van vandag. 'Its practitioners would say they have shifted hermeneutics out of the realm of merely explaining, to providing an in-depth understanding of human existence' (Klein, Blomberg \& Hubbard 1993:106).

\section{Verstaan binne hermeneutiek}

Hermeneutiek het te doen met verstaan: die verstaan van tekste binne konteks, verduideliking, verheldering, vertaling en die kommunikasie van 'n boodskap. Dit poog om te interpreteer en te vertolk vir mense wat wil hoor en verstaan (Louw 1999:561). Hermeneutiek poog om ons te help om te verstaan hoe verstaan werk. Wie met hermeneutiek besig is, is met hom- of haarself besig. Deur die hermeneutiek leer ons onsself ken, want ons begryp iets van die manier waarop ons en ook ander 'n teks lees en verstaan (Le Roux 2009). Daarom kan hermeneutiek selfs as 'n lewensfilosofie verstaan word. Vos (1996:14, vgl. Jeanrond 1991:56) wys daarop dat hermeneutiek daarop gerig is om menslike verstaan en selfverstaan te bevorder, en as sodanig as praktiese filosofie beskryf kan word.

Deelnemende begrip beteken dat daar van binne af probeer word om as deelnemer die spesifieke situasie en die persoon se ervaringe te verstaan. Subjektiewe begrip, dit wil sê dit wat sin aan 'n eie werklikheid gee, moet ondersoek word.

Elke individu gee sin aan sy handelinge deur sy subjektiewe begrip of interpretasie daarvan. Elkeen se worsteling, twyfel of vrae moet dus in hierdie lig gerespekteer en van binne af verstaan probeer word. Omdat elke individu uit sy eie begripskonteks binne sy leefwêreld ' $n$ ander individu se leefwêreld betree, is ontmoeting en dialoog nooit neutraal of absoluut en afgesluit nie (Bothma 2003:100). Een van die belangrikste faktore wat daartoe bydra dat ' $n$ persoon tot molestering oorgaan, is as hy self as kind gemolesteer is. Dit word die slagoffer-tot-mishandelaar-siklus (victimto-abuser cycle) of mishandelde-mishandelaar-verskynsel (abused-abusers phenomenon) genoem (Hall \& Hall 2007:464). Die wortels van pedofilie word in die kinderjare gevind (Howitt 1995:34; Potgieter 1997:181) en die wanorde ontwikkel gedurende adolessensie. Begrip vir pedoseksuele 
afwykende gedrag wil nie aan 'n persoon die reg gee om kinders te molesteer nie. Daar is immers persone wat as kind gemolesteer is en wat nie seksuele oortreders word nie (Pryor 1996:59; Powell 2007:9; Briggs 1995:10; Carney \& Dew 2003:268).

Die pastorale terapeut stap saam met die deelnemer deur sy verlede en luister na wat hom gedring het om kinders seksueel te molesteer. Hierdie redes gee nie aan hom die reg om kinders te molesteer nie, maar help die terapeut om die oorsprong van sy afwykende gedrag te identifiseer.

\section{Eie oordele aangaande pedofilie en eie seksualiteit}

Om suksesvol met persone wat kinders molesteer te kan werk, is dit noodsaaklik dat die pastorale terapeut gemaklik sal wees met sy of haar eie seksualiteit en ook met die seksualiteit van ander. Die verhale waarna geluister word, kan die terapeut wat innerlike konflik beleef, veral met betrekking tot seksuele kwessies, traumatiseer (Potgieter 2009:251).

Die pastorale terapeut se eie oordele aangaande pedofilie moet uitgeklaar word. Soos die res van die samelewing mag die pastorale terapeut ook die pedofiel as ' $n$ monster etiketteer. Deur tyd saam met hierdie persone te bestee, het ek as pastorale terapeut baie geleer. Ek het hulle swakheid, hulle gebrek aan karakter en hulle verwronge waardesisteem wat hulle toestemming gee om te molesteer, raakgesien. So 'n persoon is vasgevang in sy eie web van innerlike angs, sowel as ' $\mathrm{n}$ patroon wat van geslag tot geslag oorgedra is. Daar is geen verskoning vir sy dade nie (Pryor 1996:59; Powell 2007:9; Briggs 1995:10; Carney \& Dew 2003:268), maar daar is redes voor, en om hierdie redes te verstaan, kan 'n mate van vrede gee.

Die patologiese gedrag kan natuurlik nie goedgekeur of goedgepraat word nie. Daar moet vermanend opgetree word, maar as daar in pastorale berading slegs op die gebruik van bybelse beginsels gefokus word, word daar vanuit 'n moralistiese posisie opgetree en word die deelnemer onder druk geplaas. Dit sou nie die idee van terapie met die pedofiel wees nie. Pastorale terapeute wat ' $n$ moralistiese benadering volg, konsentreer op die morele en tree met die deelnemer in gesprek oor die rol wat sonde speel. Hierdie benadering het sekerlik ' $n$ plek in pastorale berading, maar as ' $n$ enkele beradingsmetode kan dit nadelige resultate vir die pastoraat met die pedofiel inhou. In pastorale terapie met die pedofiel vind vermaning eers later in die terapeutiese proses plaas. 'n Persoon in terapie se geestesdimensie moet eers geopen word en hyself moet vrae oor sy optrede vra. Vermaning kan dus gewoonlik eers plaasvind wanneer die pedofiel insig in sy seksuele probleem kry (Potgieter 2009:194-198).

As 'n mens 'n persoon met seksueel afwykende gedrag wil verstaan, moet ' $n$ mens sy agtergrond en sy verlede verstaan, want dit is as 't ware waar die afwykende gedrag gevoed en gevorm is:

If we really want to understand this crime, then we need to accept this fact - that most child molesters are not monsters. They are human beings who might have more in common with us than not. (Schultz 2005:2)
Louw (2003:42) stel dit soos volg: 'Understanding is an attempt to penetrate, through the word of a text, into the initial hidden meaning or intention of a text.' Gadamer (1982:77) wys daarop dat begrip op grond van dialogiese gesprek plaasvind. 'n Egte dialoog vereis 'openheid' (Van Veuren 1995:148). Hierdeur verkry die woord self ' $n$ hermeneutiese funksie (Palmer 1977:139). Die hermeneutiese funksie van taal dui daarop dat die ware grondslag van taal geleë is in die verskynsel van praat, want deur te praat word iets aan die lig gebring ( 1 Kor 4:5) en word betekenis oorgedra (Labuschagne 2008:870). Palmer (1977:53) wys daarop dat die primêre verskynsel van verstaan nie die verstaan van taal is nie, maar verstaan déúr taal. Dit is aanvanklik 'n proses om die persoon met afwykende seksualiteit te help om sy gevoelens en denke in taal oor te dra. Wanneer daar vertroue en 'n openheid tot stand gebring is, kan die waarheid gesoek word.

\section{Van kundige na onkundige en ko-konstrueerder}

Dit is belangrik dat die gespreksgenoot moet aanvoel dat die pastorale terapeut verstaan. Hy moet as ' $n$ individu beskou word en nie as 'n klas of 'n oortreder nie. Hierdeur kan wedersydse vertroue tussen deelnemer en pastorale terapeut opgebou word (Louw 2008:253). Teologiese begrip is 'n proses. Ware begrip verg immers betrokkenheid (B.A. Müller 1996:24). Terapie met die pedofiel moet as 'n pastorale, hermeneutiese avontuur bestempel word waar die terapeut as fasiliteerder van 'n egte, betekenisvolle soeke na $\sin$ in hierdie persoon se lewe optree. Die pastorale terapeut tree slegs as gids op wat die deelnemer bystaan in die proses om nuwe moontlikhede daar te stel, en 'n gesprek fasiliteer met die oog op 'n uitkoms wat toegevoegde waarde, sin en betekenis insluit (Janse van Rensburg 1999:160). Die pastorale terapeut kan 'n persoon slegs help as ko-konstrueerder (Kvale 1992:13) en moet versigtig wees om deskundige kennis op hom af te dwing. Sodoende kan die pastorale terapeut in die verhaal van die oortreder inloop met die grondhouding van onkundigheid, van not knowing (Potgieter 2009:250). Om nie die kundige te wees nie, behoort 'n bevrydende ervaring vir die pastorale terapeut te wees (Kotzé \& Kotzé 1997:42; Müller 2000:71). Die terapeut is bevry om gaandeweg meer oop, deursigtig en kongruent te kan wees, om net haarself te wees, en die terapeutiese masker te kan afhaal, sonder om doeltreffendheid en professionaliteit prys te gee. Louw (1999:346) en Janse van Rensburg (1999:160) poneer dat die terapeut nie die kundige is nie, maar slegs 'n gesant van God in dienskneggestalte (Luk 22:27). Die deelnemer beskik in elk geval oor meerdere kennis van sy omstandighede.

Die hermeneutiese benadering is nie ' $n$ passiewe proses nie. Die pastorale terapeut is aktief betrokke in die terapeutiese proses saam met die deelnemer.

\section{Nie'n passiewe proses nie}

Terapie is nie iets wat aan die pedofiel gedoen kan word nie. Dit is eerder ' $n$ gesamentlike poging deur die pastorale terapeut en deelnemer. Daarom moet die pastorale terapeut eerder 'n ko-konstrueerder wees wat die deelnemer in die konteks van sy probleem probeer verstaan en 'n selfverstaan 
by hom fasiliteer. Alhoewel terapie ongestruktureerd behoort te wees, is dit belangrik dat die pastorale terapeut hom- of haar sal inlig ten opsigte van vrae en teorieë aangaande pedofilie. Omdat daar baie vrae by die persoon in terapie ontstaan, behoort die pastorale terapeut aanpasbaar en plooibaar in die terapeutiese proses te wees. Wanneer die terapeut en persoon saam na 'n oplossing en antwoorde op vrae soek, kan die persoon telkens 'n stappie nader aan die beheer en bestuur van sy seksuele afwykende gedrag kom (Potgieter 2009:168-187).

Vrae wat by die deelnemer in terapie mag opkom, is onder andere: Kan pedofilie 'n demoniese binding wees? Is dit 'n erfsonde? Die sondevraagstuk en vrae oor vergifnis kom ook dikwels voor. Pastorale terapie met die pedofiel sal verskil van persoon tot persoon, en die terapeut sal moet leer om te wag vir die persoon, want telkens is dit 'n unieke, eiesoortige, skeppende proses.

In pastorale terapie met die pedofiel is samewerking tussen die terapeut en die pedofiel van kardinale belang. Indien die terapeut nie die persoon en sy probleem aanvaar nie, kan daar nie saamgewerk word nie en kan daar nie voldoende interne en eksterne ondersteuning wees nie. Die hermeneutiese benadering van verstaan verg ' $n$ houding van onvoorwaardelike aanvaarding (Potgieter 2009:135-136).

\section{Onvoorwaardelike aanvaarding}

Fourie (2006:107) beklemtoon dat dit die terapeut se taak is om te verstaan, te verklaar en gepas in te gryp om sodoende genesing of groei te bewerkstellig. Die pastorale terapeut se taak is nié om te veroordeel nie. Die psigoloog Carl Rogers (1959:184-256) het in dié verband 'n groot invloed op die pastoraat gehad. Sy waarde van onvoorwaardelike aanvaarding klop met die teologiese waarde van die pastoraat.

Die pastorale terapeut moet geroepe voel om met persone wat aan seksuele afwykende gedrag ly, te werk. Daar moet inbeweeg word in die onrustige wêreld van'n seksmisdadiger en tog moet daar 'n veilige, emosionele afstand gehou word. Om met hierdie oortreders te werk, moet 'n spirituele en professionele roeping wees, omdat dit baie harde werk is. Sweeney (2008:9) sê egter: 'The One who calls, provides the resources.' Hy noem verder dat daar in terapie altyd aan die méns in terapie gedink moet word. Elke mens soek immers iemand, of 'n plek waar hy of sy onvoorwaardelik aanvaar word vir wie hy of sy is, sonder enige angs oor verwerping, isolasie, onregverdige diskriminasie, en sonder die vrees dat hy of sy op skuld en foute vasgepen sal word.

Die mees fundamentele, ware genesing van die menslike siel gebeur wanneer'n persoon die intimiteit van onvoorwaardelike aanvaarding ervaar. Dit gebeur wanneer ' $n$ persoon aanvaar word vir wie hy of sy is, sonder enige vrees vir verwerping. Holistiese, geestelike genesing hou verband met die onvoorwaardelike liefde wat God bied en wat heling in alle dimensies bring (Louw 2008:67).
Êrens soek mense na 'n leefruimte waar liefde konkreet beteken: versoening, vergifnis en genade. Vir Crabb (1997) gaan dit om 'n opregte binding met die mens-in-nood:

The most powerful thing we can do to help someone change is to offer them a rich taste of God's incredible goodness in the New Covenant. He looks at us with eyes of delight, with eyes that see a goodness beneath the mess, with a heart that beats wildly with excitement over who we are and who we will become. And sometimes he exposes what we are convinced would make him turn away in disgust in order to amaze us with his grace. That's connecting. When we connect like that, it can change people's lives. (bl. 10)

Hierdie woorde van Crabb (1997) vestig die aandag op 'n wederkerige proses binne die hermeneutiese konteks. Die deelnemer moet onvoorwaardelike aanvaarding beleef, soortgelyk aan die liefdesbinding wat daar tussen God en sy kinders bestaan. Sowel die terapeut as die deelnemer word aan God se liefde blootgestel (Louw 2007:253). Hierdie benadering vind aansluiting by die verbondsooreenkoms tussen God en die mens.

Van albei kante is onvoorwaardelike, absolute aanvaarding kompleks. Dit is nie maklik vir 'n persoon wat kinders molesteer om hom te ontbloot nie. Daar moet verstaan word dat dit vreesaanjaend moet wees om mense toe te laat om jou te sien soos jy is: die duisternis in jou hart, al jou slegte gewoontes, alles wat jy in die verlede gedoen het en waaroor jy miskien tot op hede nog nie berou het nie, al jou vooroordele, jou tekortkominge en jou swakhede (Bell 2007:136).

In pastorale terapie met 'n seksuele oortreder kan daar aanvaar word dat hy deur fases beweeg wanneer hy gevra word om homself te ontbloot. Dié fases behels dat hy die pastorale terapeut sal mislei, dat daar aanvanklik dialektiese spanning en angstigheid by hom sal wees, dat hy aanvanklik gebeure sal versier of dramatiseer en leuens vertel. Hy kan slegs geleidelik die waarheid in die oë kyk.

Hierdie artikel is nie gerig op persone in die gevangenis nie, maar tot 'n groot mate op die persoon wat bewus is van sy seksuele afwykende gedrag en binne die samelewing woon en werk. Persone wat gevangenisstraf vir kindermolestering uitdien, wil baie keer hulle bekendmaking misbruik tot voordeel van hulle vrylating.

\section{Interpretasie binne hermeneutiek}

Schmidt (2006:1) definieer hermeneutiek as interpretasie. Hermeneutiek word aangewend in omstandighede waar daar deur middel van interpretasie na betekenis gesoek word wat nie direk afgelees kan word nie (Gadamer 1976:xii). Pastoraat met die pedofiel vereis interpretasie met 'n sensitiewe ingesteldheid, sodat daar insig in die deelnemer se handelinge en keuses verkry kan word. Daar vind ook 'n wisselwerking van interpretasie tussen terapeut en deelnemer plaas wat die deelnemer help om ryker betekenis te ontdek as wat 'n persoon op sy eie sou kon doen.

Die pastorale terapeut moet ook versigtig wees, want nóg finale interpretasies nóg een korrekte interpretasie is moontlik. Die proses van verstaan verander ook interpretasie. 
Interpretasie onthul die moontlikhede van menslike ervaring vir die interpreteerder. Dit is die opbouende funksie van interpretasie. Op sekere tye en op 'n sekere plek lig dit die gevormde persoon bo die besondere omstandighede en grense van sy of haar lewe uit, en gee daaraan 'n soort universaliteit (Van Veuren 1995:147).

\section{Ervarings binne hermeneutiek}

Menslike ervaring en handelinge kan slegs doeltreffend bestudeer word wanneer die bedoelings, waardes en intensies waarop handelinge gegrond is, verstaan word (Pieterse 1993:73).

In die verstaanproses speel empiriese elemente (menslike ervaring) 'n rol (Louw 1999:119). Die begrip empirie word in ' $n$ breër konteks gebruik as in die enge betekenis van sintuiglike waarneming. Dit verwys na die geheel van die kernproses se verstaans- en interpretasiekomponente waarbinne eksistensiële, kontekstuele en relasionele elemente 'n belangrike rol speel. Empirie sluit derhalwe eksistensiële houding, nabetragting, gesindhede, waardes, situasies, kwaliteite, uitwerkinge en handelinge in. Dit gaan dus in die empiriese benadering nie bloot om sintuiglike waarneming, meetbare prosesse, logiese verklarings en gekwantifiseerde statistiek nie, maar om ervaring as:

- 'n netwerk van verhoudinge (stelsel van relasies), handelinge en kenprosesse

- 'n dinamiese en eksistensiële proses van verstaan, interpretasie en aanduiding (Louw 1999:120-121).

Empirie verwys dus na die totale proses van interpretasie met die noukeurigheid en betroubaarheid van gegewens (Louw 1999:120-121).

Pastorale hermeneutiek in terapie met die pedofiel sou dus kwalik sonder 'n empiriese moment kon funksioneer (Louw 1999:119).

\section{Pastorale hermeneutiek}

Pastorale hermeneutiek poog om die metafore van sorg, hulp en troos hoofsaaklik binne die raamwerk van die Skrif en die kerklike tradisie te verstaan en te vertolk in terme van die mens, sy eksistensiële ervaringswêreld en sy kultuurkonteks (Louw 1999:561). Pastorale hermeneutiek beteken dat die pastorale terapeut ' $n$ taak het om God se teenwoordigheid en verhaal vir die mens in nood te vertolk. Dit beteken ook om die pedofiel se spirituele behoefte en nood in die lig van God se genade en liefde te vertolk, sodat dit sin sal maak in sy lewe. J.C. Müller (1996:173) wys daarop dat daar 'n hermeneutiese proses geïnisieer moet word waardeur dit vir die persoon in berading moontlik word om sy storie in die lig van dié Verhaal te interpreteer. Hier het ons te doen met die sogenaamde pastorale hermeneutiek.

Die doel is dus om te fokus op die konkretisering en toepassing van die heilsboodskap in die leer en lewe van die kerk. Hierdie toepassing en verstaan van hermeneutiek kan nie anders as om verhoudingsmatig en kontekstueel verstaan te word nie:
Practical theology tries to interpret and translate the praxis of God in terms of human and existential issues through the action of communities of faith - the ministries of the church in the world. (Louw 1998:98)

In die hermeneutiese moment word die persoon in berading begelei om sy situasie en probleme in die lig van God se Woord te verstaan (Janse van Rensburg 1999:162). Die verstaanproses gaan eintlik om sensitiwiteit en verdieping van die pastorale ontmoeting tussen God en die mens (Louw 1999:11), met 'n Bybelse begrip van die mens as geskapene na God se beeld (Möller 1999: par. 3; De Bruyn 1997: par. 43.3).

Die verstaansmoment word deur ' $n$ dinamiese proses van verandering, die agogiese moment, opgevolg (Janse van Rensburg 1999:162) en beoog om 'n transformasie van die totale mens teweeg te bring (Louw 1999:95). Louw (1999:360) dui aan dat die belangrike faktore van vertolking en interpretasie by die tradisionele funksies van die pastoraat, naamlik heling, begeleiding, ondersteuning en versoening, gevoeg moet word. Dat die mens nie verklaar kan word nie, maar verstaan moet word, impliseer dat antropologie wesenlik 'n hermeneutiese probleem is (Louw 1999:157).

\section{Pastoraal teologiese antropologie binne hermeunetiek}

Omdat die pastorale terapeut in die herstrukturering van die geestelike dimensie belangstel, sou, dit vanselfsprekend wees om vanuit 'n pastoraal teologiese antropologie te werk, en nie op ' $n$ analitiese wyse na die pedofiel te kyk nie. Soos reeds genoem, moet die deelnemer eerder hermeneuties benader word vanuit sy verhouding met God en hoe hy daarvolgens sin aan die lewe kan gee (Louw 1999:181). 'n Prakties teologiese antropologie verantwoord die aanvaarding van 'n bepaalde mensbeeld, met die oog op 'n doeltreffende pastorale ontmoeting en die terapeutiese effek wat so 'n ontmoeting vir die pedofiel inhou (Louw 1999:153). Dit gaan van die veronderstelling uit dat God aan die deelnemer as mens 'n sentrale plek in die aardse skepping gegee het. Daarom moet hierdie deelnemer tot verantwoordelike besluitneming in die normatiewe dimensie begelei word.

God het die mens na sy beeld geskape en aan hom bepaalde opdragte gegee en beloftes gemaak. Een van hierdie beloftes is die ewige lewe, wat vir die deelnemer miskien nie ' $n$ werklikheid is nie. Daarom moet die persoon vanuit 'n skeppings- en herskeppingsperspektief benader word, met die oog op geloofsgroei en versoening met Christus (Louw 1999:298). Volgens Louw (1999:203) is die mens 'n eenheidswese, wat vanuit die perspektief van siel, gees en liggaam beskryf kan word. Louw (2008:100) praat ook van 'n embodied soul. Die mens is vleeslik en aardsgebonde, en daarom swak, broos, sterflik en afhanklik van die verhouding met God. Die mens is ook 'n redelike wese met 'n sedelike bestemmingsfunksie waar herinnering, motiewe en impulse as ' $n$ innerlike realiteit, in kombinasie met die gewete, erken word. Dit definieer die mens as 'n aanspreekbare wese (Denton 2005:83). Louw (1989:22) stel dit dat die mens 'n totale wese is met 'n strukturele gerigtheid op God, op lewe 
as 'n aangrypingspunt en op veranderingsgebeure deur die werking van die Heilige Gees. 'n Pastorale antropologie benader en behandel die mens as skepsel en beeld van God (Janse van Rensburg 1987:208).

In hierdie proses word daar gehoop dat daar 'n fusie sal plaasvind tussen die verhaal van God en die verhaal van die deelnemer, ten einde ' $n$ nuwe storie te skep waarin die hoop en beloftes van die evangelie beeldende komponente is en sin en betekenis fasiliteer (J.C. Müller 1996:105; Louw 1999:31; Müller 2000:71).

\section{Enkele ander merkers binne die pastoraat met die pedofiel My waardes}

'n Pastorale terapeut sal die belangrikheid, maar ook die kompleksiteit en uitdagings ten opsigte van terapie met pedofilie besef.

'n Pastorale terapeut mag sy of haar eie waardes, beginsels en opinie hê en kan dit selfs deel met die deelnemer, maar dit mag nie afgedwing word nie, want dwang het geen waarde nie. Daar moet eerder gewag word dat die deelnemer binne 'n veilige ruimte van respek en agting uiteindelik eerlik oor homself en sy ervaringe kan wees (Dreyer 2005:21). 'n Persoon wat aan pedofilie ly het die volgende gesê: 'Nadat ek besef het dat dit wat ek doen, verkeerd is, het God my begin genees' (Potgieter 2009:252).

Die pedofiel rasionaliseer, minimaliseer of ontken sy dade heeltemal. Hierdie verdedigingsmeganismes verhinder hom om sy probleem doeltreffend te hanteer, sodat inligting geïntegreer kan word en groei kan plaasvind (Potgieter 2009:184-185). Voorbeelde van rasionalisering en minimalisering is onder andere: Ek het net gevat, nooit ' $n$ kind gepenetreer nie, of Ek gee net liefde.

Ontkenning kan ook 'n algemene verdedigingsmeganisme wees wat die individu teen onhanteerbare stres beskerm. Dit kan ook 'n bewuste aksie wees om interne of eksterne gevolge van handelinge wat gepleeg is, te vermy (Pryor 1996:179-180). 'Maar deur die genade van God is ek wat ek is' (1 Kor 15:10).

Wanneer 'n persoon by die punt kom waar hy sy probleem aanvaar en erken dat sy lewe buite beheer geraak het, is dit vir hom maklik om te erken dat hy self al beheer probeer neem het, maar nie in staat was om van hierdie verslawende afwykende gedrag afstand te doen nie. Dit is dan wanneer hy besef:

Ek kan nie my seksuele impulse self beheer nie, dit is buite myself. God gee my die krag wat ek nodig het om oor my seksueIe impulse beheer te neem. (Hart 1994:201)

Hy moet besef en glo dat die krag van God, wat groter as hyself is, genesing (beheer en bestuur) kan bewerkstellig. Hy moet ' $n$ besluit neem om sy eie wil en lewe aan God se sorg toe te vertrou (Carnes 2001:170). Eers dan kan 'n persoon by sondebesef kom, en sondebelydenis en vergifnis in die vooruitsig wees.
Om alleen seksueel afwykende gedrag te probeer oorkom, word deur Hart (1994:202) as hopeloos bestempel. Hy noem verder dat die menslike brein wonderlik is, maar ook sy beperkings het. Daarby staan mans magteloos teenoor testosteroon en is die seksuele drang een van die sterkste drange in die mens.

Die belangrikheid van 'n vertrouensverhouding met die seksuele oortreder kan nie genoeg beklemtoon word nie. Baie persone in hierdie situasie vrees dat hulle ook deur die terapeut veroordeel gaan word (Fourie 2006:107). Die vestiging van 'n vertrouensverhouding, en die daarstelling van 'n atmosfeer wat bevorderlik is vir die gespreksituasie is, kan as die hoofdoelwit van terapie gesien word, veral by ' $n$ eerste ontmoeting (Louw 1999:416).

\section{Vertrouensverhouding}

Die verhouding met die pedofiel is ook belangrik, omdat dit miskien die eerste keer is dat hy 'n ander verhouding as 'n seksuele verhouding aanknoop (Marais 1990:36). Die verhouding met die pastorale terapeut is ook vir hom 'n primêre verhouding, want deur hierdie verhouding word hy geleer om te hersosialiseer. Die pedofiel het gewoonlik gebrekkige sosiale vaardighede (Flora 2001:75; Wolfaardt 2003:150), 'n swak selfbeeld (Sweeney 2008:9; Hall \& Hall 2007:462; Hall \& Lloyd 1993:67) en min selfvertroue (Sweeney 2008:9; Schultz 2005:22). By die pastorale terapeut kan hy leer dat hy 'n verhouding met iemand kan hê en al sy emosies kan toon, sonder die seksuele. Daar sal baie tyd aan die bou van ' $n$ vertrouensverhouding bestee moet word om sodoende sy wese binne te dring en groter openheid te kan verseker. So word uiteindelik sagter grense geskep, wat die vloei van inligting kan bewerkstellig.

As gevolg van die kompleksiteit en die uitdaging hierby betrokke, sal die pastorale terapeut hom- of haarself nie van Goddelike bystand en gebed kan distansieer nie.

\section{Gebed en afhanklikheid}

Foster (1989:54) dring aan op gebed vir persone met seksuele afwykende gedrag, alhoewel daar deur die wetenskappe geglo word dat dié afwyking ongeneeslik is en slegs beheer en bestuur kan word. Deur opregte gebed kan daar beslis 'n permanente verandering kom. Seks is soos 'n rivier - dit is 'n wonderlike en goeie seën wat binne die regte kanale gebruik moet word. 'n Rivier wat sy walle oorstroom, is gevaarlik, en so ook perverse seksuele drange. God se bedoeling is dat seks beperk word tot man en vrou binne die huwelik. Wanneer 'n mens vir 'n persoon met seksuele afwykings bid, kan jy jou verbeel dat die rivier wat eens sy walle oorstroom het, teruggebring word na sy oorspronklike vloei wanneer God betrek word.

Die krag en reinigende teenwoordigheid van die Heilige Gees sal in die pastorale situasie in gebed gevra gevra word, omdat die terapeut self sonde en tekortkominge het. Die pastorale terapeut sal spontaan vir hom- of haarself en vir die hulpsoekende bid. 
Die terapeut moet egter sensitief vir, of eerder afhanklik van, die leiding van die Heilige Gees in die pastorale situasie wees. Crabb (1997:43) poneer dat'n pastorale terapeut bewus moet wees van sy of haar eie geestelike verbondenheid in Christus. Sonder die besef van geestelike verbondenheid kan 'n pastorale terapeut nie in terapie met die pedofiel staande bly nie.

Die terapeut moet ook doelgerig as pastorale terapeut optree. Hy of sy moet deurgaans bewus wees van die geestelike dimensie van sy of haar rol en moenie die psigiatriese rol probeer oorneem nie. Soos reeds genoem, behoort die pastorale terapeut deel van die holistiese program te wees.

\section{Tydrowende proses}

Om 'n pedofiel te oortuig dat dit wat hy doen verkeerd is, is 'n tydrowende taak. Daarom moet die pastorale terapeut hom- of haarself vir 'n onbeperkte tyd beskikbaar stel. Baie wonderwerke gebeur, maar dit gebeur nie in alle gevalle nie (Hart 1994:98-99). Seksuele afwykende gedrag is magtig en dompel 'n persoon in 'n diep en donker gevangenis. Wellus kan 'n mens daartoe dryf om skrikwekkende dinge te doen. Dit kan jou oorweldig, jou gedagtes heeltemal oorheers en jou ellendig laat voel (Bell 2007:53). Daarom is dit nooit 'n voltooide proses nie, maar ' $n$ kreatiewe, aaneenlopende proses.

Navorsers (Salter 1995:44; O’Hagan 1993:194, 197; Wolfaardt 2003:382; Labuschagne 1995:25) beweer dat dit'n lewenslange proses is. Die algemene volwasse program duur ongeveer drie jaar en dié vir die jeugdige oortreder ongeveer 18 maande tot twee jaar. Die behandeling hang af van die vlak van betrokkenheid in pedofilie, die tipe bedrywighede, en die persoon se toerekenbaarheid en verantwoordelikheidsbesef.

\section{Slot}

Die seksuele misbruik van kinders is 'n omvangryke maatskaplike probleem. In Suid-Afrika bestaan daar geen rehabilitasieprogramme vir persone wat kinders molesteer en wat self as kind gemolesteer is nie. In die pastoraat is daar 'n totale leemte. Die pedoseksuele persoon is nie net 'n ou man wat met 'n groot jas in parke rondloop en kinders soek om te molesteer nie. Dit is persone wat tussen ons werk en leef wat hierdie diep, donker geheim in hulle ronddra. Die geestelike gevolge wys dat pastorale begeleiding onontbeerlik is in die helingsproses. Pastorale terapeute is huiwerig om hulle vir hierdie proses beskikbaar te stel vanweë simpatie met die slagoffer, die intense stigma wat aan oortreders kleef, en die aanname dat pedoseksualiteit nie genees kan word nie. Navorsing wys dat die geestelike dimensie van die pedoseksuele persoon totaal ontwrig is. Indien die pastoraat toetree tot hierdie dimensie, sal die probleem beheer en bestuur kan word.

Voordat 'n persoon hom- of haarself beskikbaar stel vir die pastoraat met ' $n$ pedoseksuele persoon, moet hy of sy hom of haar eers posisioneer. Vir hierdie proses is ' $n$ hermeneutiese benadering onontbeerlik. Daar word deur middel van begrip deur interpretasie na betekenis gesoek om die persoon se geestelike nood in die lig van God se genade en liefde te vertolk, sodat dit sin sal maak in sy lewe. Die pastorale terapeut moet onder andere gemaklik wees met sy of haar eie seksualiteit; eie oordele moet uitgeklaar word. Dit is nodig ten einde aan die pedoseksuele persoon 'n veilige en onvoorwaardelike aanvaarding te bied, sodat hy sonder angs en vrees vir verwerping tot die herskepping van sy geestelike sy kan toetree.

Ek vertrou dat hierdie navorsing pastorale terapeute sal aanmoedig om hulleself te bemagtig, sodat die pastoraat 'n bydrae kan lewer ten bate van die persoon wat kinders molesteer, maar ook ten bate van die samelewing.

\section{Erkenning Mededingende belange}

Die outeur verklaar dat sy geen finansiële of persoonlike verbintenis het met enige party wat haar nadelig kon beïnvloed in die skryf van hierdie artikel nie.

\section{Literatuurverwysings}

American Psychiatric Association, 2000, Diagnostic and statistical manual of mental disorders, 4th edn., American Psychiatric Association, Washington.

Bell, R., 2007, Seks God, Struik Christelike Boeke, Kaapstad.

Bothma, J.D., 2003, 'Pastorale terapie met die MIV/VIGS geaffekteerde familie: 'n Narratiewe benadering', PhD-proefskrif, Universiteit van die Vrystaat.

Briggs, F., 1995, From victim to offender: How child sexual abuse victims become offenders, Allen \& Unwin, Crows Nest.

Britz, L., 2003, "n Intervensiemodel vir die middelkinderjare-kind wat seksueel misbruik is', DPhil-proefskrif, Universiteit van Pretoria.

Carnes, P., 2001, Out of the shadows: Understanding sexual addiction, Hazelden, Centre City, MN.

Carney, M.P. \& Dew, B.J., 2003, 'Online experiences of sexually compulsive men who have sex with men', Sex Addiction \& Compulsivity 10, 259-274. http://dx.doi. org/10.1080/713775414

Crabb, L.J., 1977, Effective Biblical counseling, Zondervan, Nashville, TN.

Crabb, L.J., 1997, Connecting: A radical new vision, Word Publishing, Nashville, TN.

De Bruyn, P.J., 1997, Jou enigste troos: Die Heidelbergse kategismus vir die hedendaagse mens, Departement Sentrale Publikasies, PU vir CHO, Potchefstroom. PMCid:1904703

Denton, R.A., 2005, 'Die adolessent wat mishandel is se verhouding met God: ' $n$ Pastorale gestaltbenadering', MA-verhandeling, Universiteit van Suid-Afrika.

Dreyer, Y., 2005, 'Vergewe en vergeet: 'n Pastorale perspektief', Verbus et Ecclesia 26(1), 16-34.

Flora, R., 2001, How to work with sex offenders, A handbook for criminal justice, human service, and mental health professionals, The Haworth Clinical Practice Press, New York, NY.

Foster, R., 1989, Celebration of discipline, Clays, London.

Fourie, K., 2006, 'Vir die pedofiel of verkragter', in M. Maartens (red.), Deur trauma, bl. 106-107, Lapa, Pretoria.

Gadamer, H.G., 1976, Philosophical hermeneutics, University of California Press, Berkeley, CA.

Gadamer, H.G., 1982, Truth and method, Crossroad, New York, NY.

Hall, R.C.W. \& Hall, R.C.W., 2007, 'A profile of pedophilia: Definition, characteristics of offenders, recidivism, treatment outcomes, and forensic issues', Mayo Clinic Proceedings 82(4), 457-471. http://dx.doi.org/10.4065/82.4.457, PMid:17418075
Proct

Hall, L. \& Lloyd, S., 1993, Surviving child sexual abuse, The Falmer Press, London.

Hart, A.D., 1994, The Hart report: The landmark study of men and sex in the 90's. The sexual man. Masculinity without guilt, Thomas Nelson, Nashville, TN.

Hesselink-Louw, A.E. \& Schoeman, M., 2003, 'Treatment of incarcerated sex offenders in South Africa: An analytical perspective, Acta Criminologica 16(1), 158-173.

Howitt, D., 1995, Paedophiles and sexual offences against children, Wiley, Chichester.

Janse van Rensburg, J., 1987, "n Kritiese ondersoek na die moontlike gebruik van hipnose in die psigo-pastorale arbeid', DTh-proefskrif, Universiteit van Suid-Afrika.

Janse van Rensburg, J., 1999, 'Etiek en pastoraat in hermeneutiese konteks', Tydskrif vir Geesteswetenskappe 39(2), 158-167. 
Janse van Rensburg, J., 2000, The paradigm shift: An introduction to postmodern thought and its implications for theology, Van Schaik, Pretoria.

Jeanrond, W.G., 1991, Theological Hermeneutics: Development and Significance, Macmillan, London.

Klein, W.W., Blomberg, C.L \& Hubbard, R.L., 1993, Introduction to Biblical interpretation, Word Publishing, Dallas, TX.

Koch, S., 1959, Psychology: A study of a science, McGraw-Hill, New York, NY. PMCid:290431

Kotzé, E. \& Kotzé, D.J., 1997, 'Social construction as a postmodern discourse: An epistemology for conversational therapeutic practice', Acta Theologica 17(2), 27-50.

Kvale, S., 1992, 'From the archaeology of the psyche to the architecture of cultura landscapes', in S. Kvale (ed.), Psychology and postmodernism, pp. 1-19, Sage Publications, London.

Labuschagne, I., 1995, 'Kindermolestering en verkragting: Die howe se rol', Consultus (1), 20-26.

Labuschagne, J.P., 2008, 'Die hermeneutiek van kerkgeskiedenis en "teologiegeskiedenis": 'n "Nuwe paradigma" vir kerkgeskiedenis', Hervormde Teologiese Studies 64(2),861-883.

Le Roux, J., 2009, Hermeneutiek help ons om te verstaan, besigtig op 12 Februarie 2011 by http://teo.co.za/artikel/articles/205/1/Hermeneutiek-help-ons-om-teverstaan/Bladsy1. html

Louw, D.J., 1989, 'Die ontwerp van 'n teologiese antropologie as basisteorie vir 'n effektiewe pastorale bediening', in A.J. Smuts (red.), Predikant en Praktyk: Teologiese en Sielkundige Perspektiewe, bl. 4-29, Academica, Pretoria.

Louw, D.J., 1998, A pastoral hermeneutics of care and encounter: A theological design for a basic theory, anthropology, method and therapy, Lux Verbi, Kaapstad.

Louw, D.J., 1999, Pastoraat as vertolking en ontmoeting: Teologiese ontwerp vir ' $n$ basisteorie, antropologie, metode en terapie, Lux Verbi. BM, Wellington.

Louw, D.J., 2003, 'The paradigmatic revolution in practical and pastoral theology: From metaphysics (substantial thinking) to empirism (experiential thinking), from theism to theopschitism (hermeneutical thinking)', Practical Theology in South Africa 18(2), 3-57.

Louw, D.J., 2007, Waarom lewe ek? Hulde aan die Hoop, Naledi, Kaapstad.

Louw, D.J., 2008, Cura Vitae, illness and the healing of life, Lux Verbi. BM, Wellington.

Marais, C., 1990, Children of sorrow: Child sex abuse in South Africa, Ashanti, Rivonia.

Möller, F., 1999, Woorde van lig en lewe: 'n Dogmatiese studie, Evangelie Uitgewers, Westhoven

Müller, B.A., 1996, Skrifgebruik in die pastoraat, NG Kerk-Uitgewers, Kaapstad.

Müller, J.C., 1996, Om tot verhaal te kom: Pastorale gesinsterapie, RGN, Pretoria.

Müller, J.C., 2000, Reis-geselskap: Die kuns van verhalende pastorale gesprekvoering, Lux Verbi. BM, Wellington.
O'Hagan, K., 1993, Emotional and psychological abuse of children, Open University Press, Buckingham.

Palmer, R.E., 1969, Hermeneutics, Northwestern University Press, Evanston, IL.

Palmer, R.E., 1977, Hermeneutics, Northwestern University Press, Evanston, IL.

Pieterse, H.J.C., 1993, Praktiese teologie as kommunikatiewe handelingsteorie, RGN Uitgewery, Pretoria.

Potgieter, L.M., 1997, 'Psychological case studies of child molesters', MA-verhandeling, Universiteit van die Vrystaat.

Potgieter, S.D., 2009, "n Pastoraal-hermeneutiese benadering tot pedofilie', PhDproefskrif, Universiteit van die Vrystaat, Bloemfontein. PMCid:2655590

Powell, A., 2007, Paedophiles, child abuse and the internet: A practical guide to identification, action and prevention, Radcliffe Publishing, Oxon.

Pryor, D.W., 1996, Unspeakable acts: Why men sexually abuse children, University Press, New York, NY.

Rogers, C., 1959, 'A theory of therapy, personality, and interpersonal relationships as developed in the client-centered framework', in S. Koch (ed.), Psychology: A study of a science, pp. 184-256, McGraw-Hill, New York, NY.

Ryan, G., 1989, 'Victim to victimizer: Rethinking victim treatment', Journal of Interpersonal Violence 4(93), 325-341. http://dx.doi.org/10.1177/088626089004003006

Salter, A.C., 1995, Transforming trauma: A guide to understanding and treating adult survivors of child sexual abuse, Sage Publications, Thousand Oaks, CA.

Schmidt, L.K., 2006, Understanding hermeneutics, Acumen Publishing, Stocksfield.

Schultz, P.D., 2005, Not monsters: Analysing the stories of child molesters, Rownam \& Littlefield Publishers, Lanham, MD.

Snyman, J., 1995, Wetenskapbeelde in die geesteswetenskappe, RGN Uitgewers, Pretoria.

Standford, P., 1988, Healing victims of sexual abuse, Victory House, OK.

Steyn, C.S., 2008, "n Relasionele hermeneutiek vir die praktiese teologie', Praktiese Teologie in Suid-Afrika 23(2), 248-268.

Sweeney, D.S., 2008, 'Sexual Abuse: Victims \& offenders', News from the ACC in SA 3, 8-9.

Taibbi, R., 1996, Doing family therapy: Craft and creativity in clinical practice, Guilford Press, New York, NY. PMid:8636602

Van Veuren, P., 1995, 'Hermeneutiese siening van wetenskaplike relasionaliteit', in J. Snyman (red.), Wetenskapbeelde in die geesteswetenskappe, bl. 129-188, RGN Uitgewers, Pretoria.

Vos, C.J.A., 1996, Die volheid daarvan: Homiletiek uit'n hermeneuties-kommunikatiewe perspektief, vol. 1, RGN Uitgewers, Pretoria.

Wolfaardt, L., 2003, 'Mans wat kinders molesteer: 'n Hipno-ontleding', PhD-proefskrif, Randse Afrikaanse Universiteit. 